\title{
METODE PEMBELAJARAN KITAB KUNING DI PONDOK PESANTREN DAARUN NAHDHAH THAWALIB BANGKINANG
}

\author{
${ }^{1}$ ALI AKBAR, ${ }^{2}$ HIDAYATULLAH ISMAIL \\ ${ }^{1,2}$ UIN Sultan Syarif Kasim Riau \\ ali.akbar@uin-suka.ac.id, hidayatullah.ismail@uin-suska.ac.id
}

\begin{abstract}
This paper discussed about "The Method of Learning of the Yellow Book at Daarun Nahdhah Thawalib Boarding School Bangkinang". The research was conducted with qualitative descriptive approach and the technique data collection was done by interview, documentation, and observation technique. The result of the research showed that the method of learning of the yellow book in Daarun Nahdhah Thawalib Boarding School Bangkinang used mixed method, meaning that sometimes the ustadz / ah who read it actively, while students only hear or read the reading and the explanation of the ustadz / ah. This method is known as the bandongan method. On the contrary, sometimes students are active, meaning students read and translate word by word, while ustadz / ah supervise, assess, and guide students ability maximally in mastery of yellow book material.
\end{abstract}

Kata kunci : Metode Pembelajaan, Kitab kunig

\section{A. Pendahuluan}

Pondok

merupakan salah

pesantren lembaga pendidikan utama yang tidak dapat dipungkiri eksistensi dan peranannya dalam perkembangan dunia pendidikan khususnya di Indonesia. Awalnya pondok pesantren adalah sebuah lembaga pendidikan dan pengajaran agama Islam dibawah bimbingan seorang kyai terhadap santri-santri di pondok/asrama, yang mempelajari kitab-kitab yang ditulis dalam bahasa Arab oleh ulamaulama besar sejak terdahulu. (Imam Syafe'i: 2017) Pada perkembangannya, Pondok pesantren dewasa ini bertransformasi menjadi gabungan antara sistem pendidikan tradisional yang dalam istilah pendidikan modern telah memenuhi kriteria 
pendidikan non formal serta menyelenggarakan juga pendidikan formal berbentuk madrasah dan bahkan sekolah umum dalam berbagai bentuk tingkatan dan aneka kejuruan sesuai dengan kebutuhan masyarakat masing-masing. (Marwan Saridjo: 1982, lihat juga Mujamil Qomar: 2007)

Sebagai lembaga

pendidikan, pesantren memiliki tipikal dan tradisi keilmuan yang berbeda dibandingkan dengan lembaga lainnya. (Andik Wahyun Muqoyyidin: 2014) Diantara ciri khas dari pondok pesantren adalah adalah isi kurikulum yang terfokus pada ilmu-ilmu agama, misalnya tafsir, hadits, nahwu, sharaf, tauhid, tasawuf, dan lain sebagainya dengan rujukan literatur-literatur klasik. Literatur-literatur tersebut pada umumnya memilik ciri-ciri sebagai berikut: 1) kitab-kitabnya menggunakan bahasa Arab, 2) umumnya tidak memakai syakal (tanda baca atau baris), bahkan tanpa memakai titik, koma. (Muhaimin: 1993) Inilah yang selanjutnya disering disebut dengan Kitab Kuning atau Kitab Gundul. Sejarahnya, sebagai sumber belajar, penggunaan kitab-kitab tersebut telah digunakan sejak abad ke 16 . (Muhammad Thariqussu'ud: 2012)

Pengajian 'Kitab Kuning' atau

'Kitab Gundul' ini merupakan hal yang sangat penting dalam pendidikan pesantren, sebab ini menjadi buku pegangan. Jenis 'Kitab Kuning' atau 'Kitab Gundul' sebagai literatur yang digunakan di lembaga pendidikan Islam tradisional pesantren sangat terbatas jumlahnya. Pengelompokan kitabkitab tersebut dapat diklasifikasikan kedalam bidang ilmu-ilmu syari'at dan ilmu-ilmu non-syari'at. Kelompok jenis ilmu-ilmu syari'at, yang sangat dikenal ialah kitab-kitab ilmu fikih, tasawuf, tafsir, hadits, tauhid ('aqaid), dan tarikh (terutama sirah nabawiyah, sejarah hidup nabi Muhammad Saw.). Sedangkan kelompok jenis ilmu non-syari'at, yang banyak dikenal ialah kitab-kitab nahwu sharf, yang mutlak diperlukan sebagai alat bantu untuk memperoleh kemampuan membaca Kitab Kuning (kitab gundul).

Mengingat urgensi dari pembelajaran Kitab Kuning di pondok pesantren, maka metode pembelajarannya pun mutlak perlu diperhatikan, sebab pembelajaran mesti disajikan dengan cara yang tepat agar tercapai tujuan pelajaran. Menurut Zamakhsyari Dhofier dan Nurcholish Madjid, metode pembelajaran Kitab Kuning di pesantren meliputi; metode sorogan, dan bandongan. Sedangkan Husein Muhammad menambahkan bahwa, selain metode yang diterapkan dalam pembelajaran Kitab Kuning adalah metode wetonan atau bandongan, dan metode sorogan, diterapkan juga metode diskusi (munazharah), metode evaluasi, dan metode hafalan. (Sa'id Aqiel Siradj, dkk: 2004)

Untuk itu, kajian ini bertujuan
untuk mengkaji $r$ metode
pembelajaran Kitab Kuning yang
diterapkan di Pondok Pesantren
Daarun Nahdhah Tahawalib
Bangkinang. Setting lokasi kajian ini
dipilih sebab pondok pesantren ini


merupakan pondok pesantren tertua di Kabupaten Kampar dan telah melahirkan banyak alumni yang menjadi tokoh baik di tingkat daerah maupun nasional.

\section{B. Metode Penelitian}

Penelitian ini adalah penelitian lapangan (field research), dan memilih Pondok Pesantren Daarun Nahdhah Thawalib Bangkinang Kabupaten Kampar sebagai lokasi peneltiian. Secara umum pemilihan ini didasari atas beberapa pertimbangan, selain karena Peneliti mengambil lokasi di tempat ini, selain karena peneliti adalah alumni pesantren tersebut, penelitian juga didasarkan atas beberapa pertimbangan, pertama, peneliti sudah mengetahui situasi dan kondisi pesantren. Kedua, pondok pesantren tersebut hingga kini masih menerapkan pembelajaran Kitab Kuning dan tetap mempertahankan ciri khas pembelajaran Kitab Kuning sebagai referensinya, dan ketiga, pondok pesantren tersebut telah banyak melahirkan para ilmuan dan tokoh agama yang menjadi pelopor di negeri ini.

Pendekatan dalam penelitian ini menggunakan fenomenologis, dengan harapan dapat memperoleh data-data empiris yang nantinya dapat dideskripsikan secara lebih rinci, dan lebih akurat. (Burhan Bungin: 2007) Sedangkan untuk mendapatkam data yang nyata, maka jenis penelitian yang digunakan adalah metode Kualitatif Deskriptif. Sumber data yang diperlukan dalam penelitian ini terdiri dari data primer dan data sekunder. Data sekunder diperoleh dari bahan-bahan kepustakaan, meliputi bahan hukum primer dan bahan hukum sekunder. Sedangkan data primer diperoleh dari nara sumber di lapangan melalui wawancara, observasi, dan dokumen. Dalam wawancara peneliti berinteraksi langsung dengan informan wawancara dilakukan terhadap kyai, pimpinan pondok, dan ustad/ ustadzah pengampu mata pelajaran Kitab Kuning di Pondok Pesantren Daarun Nahdhah Thawalib Bangkinang.

\section{Potret Pondok Pesantren Daarun Nahdhah Thawalib Bangkinang}

Berdasarkan observasi dan wawacara didapati informasi bahwa Pondok Pesantren Daarun Nahdhah Thawalib Bangkinang merupakan pesantren tertua di Kabupaten Kampar, bahkan di Provinsi Riau. Pondok Pesantren Daarun Nahdhah Thawalib Bangkinang merupakan kelanjutan dari Madrasah Daarul Mu'allimin pimpinan Syeh $\mathrm{H}$. Abdul Malik, yang dulunya lebih akrab disebut "thawalib/kutab" yang didirikan pada tahun 1923, dengan menggunakan sistem pendidikan halaqah dan klasikal. Namun kemudian, karena penjajahan Jepang masuk ke wilayah tersebut membuat proses pendidikan di Daarul Mu'allimin terhenti.

Akhirnya salah seorang murid almarhum Syekh Abdul Malik yang bernama almarhum KH. M. Noer Mahyuddin mengambil prakarsa untuk menghidupkan kembali 
madrasah tersebut. Beliau mengumpulkan sejumlah ulama dan tokoh masyarakat sekitarnya (Desa Muara Uwai tempat kelahirannya) untuk membicarakan kemungkinan berdirinya lembaga pendidikan berupa pondok pesantren. Kehadiran pondok tersebut menurut beliau- akan sangat banyak manfaatnya bagi generasi muda Islam di wilayah tersebut untuk masa datang.

Hasil musyawarah disepakati untuk mendirikan sebuah lembaga pendidikan. Akhirnya pada tanggal 11 Januari 1948 dibawah kepemimpinan $\mathrm{KH}$. Muhammad Noer Mahyuddin berdiri kembali pondok, dengan nama Pondok Pesantren Daarun Nahdhah Thawalib Bangkinang (disingkat PPDN-TB). Pada mulanya pendirian tersebut ditandai dengan penerimaan santri baru untuk tingkat Ibtida'iyah saja. Kemudian pada tanggal 18 Agustus 1948 pesantren tersebut membuka jenjang pendidikan tingkat Tsanawiyah dan Aliyah hingga sekarang.

Sejarah kembali berulang, belum genap pesantren itu berumur satu tahun, meletus pula agresi Belanda pada 31 September 1948. Agresi Belanda tersebut membuat para guru dan murid terpaksa mengungsi. Bahkan tak sedikit pula yang ikut bergerilya mempertahankan kemerdekaan, sehingga dikabarkan salah seorang guru pesantren tewas di tangan Belanda masa itu.

Setelah masa agresi Belanda selesai, pada tanggal 27 Desember
1950 almarhum KH. Muhammad Noer Mahyuddin kembali mengumpulkan para guru dan santri untuk melanjutkan kembali kegiatan pendidikan di pondok pesantren Daarun Nahdhah tersebut. Sekarang pesantren tersebut dipimpin oleh putra beliau Drs. $\mathrm{H}$. Syahrizulnur. Pesantren ini terletak di Kecamatan Bangkinang Seberang, tak jauh dari pusat/ibu kota Kabupaten Kampar, tepatnya Jl. Syarifuddin Syarif, $\mathrm{SH}$ Bangkinang Seberang.

Sebagai sebuah lembaga pendidikan keagamaan, Pondok Pesantren Daarun Nahdhah Bangkinang telah berperan aktif dalam mencerdaskan kehidupan bangsa, yakni memberikan pendidikan keislaman kepada para santrinya; mulai dari nahwu, sharaf, fiqih, tafsir, mantiq, akhlak, tauhid, dan mata pelajaran lainnya. Selain itu, pesantren juga memberikan pendidikan umum sesuai dengan perkembangan. Sebagian besar santrinya dididik secara formal di asrama dan mengikuti berbagai kegiatan pondok yang sudah ditentukan.

Pondok Pesantren Daarun Nahdhah Bangkinang, selain membekali para santrinya dengan pengetahuan agama dan umum, juga keterampilan membaca kitab kuning dan hafalan al-Qur'an mulai dari Tingkat Tsanawiyah hingga Aliyah. Penghafalan al-Qur 'an merupakan program penting dan wajib diikuti oleh setiap santri sesuai dengan peringkatnya.

Adapun visi Pondok Pesantren Daarun Nahdhah adalah 
"Terwujudnya lembaga pendidikan sebagai pusat pembentukan sumber daya manusia yang beriman, bertaqwa, berakhlakul karimah, menguasai ilmu pengetahun dan teknologi serta berwawasan lingkungan". Sedangkan misinya, antara lain:

1. Melaksanakan sistem pendidikan islam

2. Menumbuhkembangkan semangat keteladanan

3. Menumbuhkembangkan semangat menuntut ilmu dan penguasaan teknologi

4. Mempersiapkan peserta didik untuk memasuki pendidikan Ianjutan

5. Melaksanakan proses pembelajaran yang efektif dan efisien, bermuatan kurikulum berbasis lingkungan hidup untuk melahirkan insan yang cerdas, disiplin dan berkualitas

6. Menciptakan lingkungan yang indah, daman, dan nyaman serta beriman (idaman) bagi seluruh warga pondok pesantren

7. Menciptakan pondok pesantren yang ramah lingkungan, bersih dan sehat

8. Mewujudkan rasa cinta terhadap lingkungan dimanapun berada bagi seluruh warga pondok pesantren.

Adapun tujuan yang ingin dicapai antara lain:

1. Santri mampu membaca dan memahami teks-teks arab gundul
2. Terciptanya suasana yang agamis di lingkungan madrasah

3. Unggul dalam kegiatan keagamaan

4. Berjaya dalam perolehan nilai UN

5. Berjaya dalam kegiatan MTQ dan MQK

6. Berjaya dalam penerapan ilmu pengetahuan dan teknologi, sains dan matematika

7. Berjaya dalam pengembangan diri

8. Berjaya dalam prestasi olahraga dan kesenian

9. Berjaya dalam memberikan pelayanan dan informasi pada siswa, orang tua dan masyarakat. (http://ponpesdaarunnahdh ah.sch.id/visi-dan-misi. Diakses pada pukul 22.30 WIB tanggal 12 September 2016.)

\section{Metode Pengajaran Kitab Kuning di PonPes Daarun Nahdhah}

Metode pembelajaran merupakan cara yang digunakan untuk menyampaikan materi kepada peserta didik dalam proses kegiatan belajar mengajar. Secara umum pesantren memiliki beberapa macam metode yang digunakan dalam kegiatan pembelajaran kitab kuning atau kitab klasik. Berdasarkan hasil wawancara dan observasi, diperoleh informasi bahwa metode pembelajaran "Kitab Kuning" atau yang lebih akrab dikenal dengan 'Kitab Gundul” di Pondok Pesantren 
Daarun Nahdhah dapat dilihat sebagai berikut:

"Pengajian kitab kuning di pesantren dibedakan pada dua tingkat, yaitu tingkat Tsanawiyah dan Aliyah.

Untuk tingkat Tsanawiyah biasanya ustadz/ah membacakan, kemudian menerjemahkan serta menjelaskan isi kandungan dari teks kitab yang dibacakan, sementara santri menyimak dan ada yang menulis apa yang telah dijelaskan oleh ustadz/ahnya. Kemudian untuk timgkat Aliyah, santri diminta membacakan kitab di depan kelas secara bergantian tentang materi yang ditentukan, selanjutnya ustadz/ah dan santri lainnya menyimak dan mengoreksi bacaaan santri tersebut. Pada tahapan berikutnya ustadz/ah menjelaskannya kepada santri agar santri memahami materi pelajaran dari pengajian kitab tersebut" (Wawancara dengan Drs. $\mathrm{H}$. Mohd. Nasirnur, MA Guru Pesantren pada tanggal 16 September 2016)

Dari wawancara tersebut, maka dapat diketahui bahwa metode pembelajaran kitab kuning di pesantren Daarun Nahdhah dapat dibedakan ke dalam dua bentuk, yaitu untuk tingkat Tsanawiyah dan Aliyah. Pada tingkat Tsanawiyah, ustadz/ah membacakan kitab di depan santri kalimat per kalimat, sedang santri menyimak apa yang telah dibacakan ustadz/ah-nya. Sedangkan untuk timgkat Aliyah, santri diminta membacakan kitab di depan kelas secara bergantian tentang materi yang ditentukan, dan santri lainnya menyimak. Setelah santri selesai membacakannya, ustadz/ah meluruskan bacaan santri tersebut, dan selanjutnya menerangkannya.

Dari hasil wawancara dengan ustadz lain menyebutkan bahwa:

"Metode yang dipakai di pesantren ini adalah metode yang sudah lazim dipakai di kalangan pesantren, yakni ustadz/ah membaca, menerjemahkan, dan menjelaskan isi kitab, sedangkan santri menyimak, apa yang telah dibacakan dan dijelaskan oleh ustadz/ah-nya. Metode ini biasanya lebih dominan dipakai pada materi pelajaran nahwu, shoraf, tafsir, hadits, mushthalah hadits, fiqh, usuhul figh, tauhid, akhlak dan tarekh. Biasanya penyampaian menggunakan bahasa Indonesia, agar santri mudah mengerti". (Wawancara dengan Taufik Guru Pesantren pada tanggal 17 September 2016)

Dari wawancara tersebut, maka dapat diketahui bahwa metode pembelajaran kitab kuning yang digunakan di pesantren Daarun Nahdhah adalah ustadz/ah menyampaikan materi kepada santri dengan cara membacakan kalimat demi kalimat, kemudian menterjemahkan dan 
menerangkannya isi dari teks kitab kuning tersebut. Sedang santri mendengarkan sambil memberi arti pada kitabnya (ngesahi-jawa), sehingga mereka mampu membaca di depan kelas bila disuruh ustadz/ah membacakannya.

Hal senada juga diperoleh informasi dari ustadz lain, yang menyebutkan bahwa:

"Pengajian kitab kuning yang diterapkan di pesantren adalah ustadz/ah membacakan sedangkan santri menirukan sesuai dengan apa yang dibacakan oleh ustadz/ah, kemudian menerjemahkan serta menjelaskan kandungan bacaan dari kitab tersebut. Setelah itu, iustadz menunjuk salah seorang dari santri untuk mengulangi bacaan yang sudah dibacakan bersama tersebut, dan lainnya menyimak dan mengoreksi pengulangan bacaan tersebut". (Wawancara dengan Muhammad Yasir Guru Pesantren pada tanggal 17 September 2016)

Dari wawancara tersebut, dapat diketahui bahwa metode pembelajaran kitab kuning yang digunakan di pesantren adalah ustadz/ah membacakan kalimat demi kalimat, kemudian santri menirukannya, selanjutnya ustadz/ah menterjemahkan dan menerangkannya. Setelah itu, ustadz/ah menunjuk salah seorang dari santri membacakannya kembali di depan kelas, sedang santri lain menyimak sambil mengoreksinya.

Kemudian dari hasil wawancara dan obsevasi yang dilakukan baik terhadap ustadz/ah maupun santri Pondok Pesantren Daarun Nahdhah Bangkinang, diperoleh informasi bahwa:

"Selain kegiatan kurikuler, pesantren menerapkan pula kegiatan berupa extra kurikuler secara rutin, yaitu pengajian asrama dalam bentuk muzakarah (diskusi) secara berkelompok. Kegiatan ini dimaksudkan untuk membantu dan memperlancar santri dalam pengkajian kitab kuning, mulai dari cara membaca, menterjemah dan memahaminya, terutama bagi santri yang kurang lancar membaca kitab kuning atau rendahnya pengetahuan ilmu i'robi/qawa'id dan menterjemah. Pengajian kelompok (muzakarah) ini dilaksanakan mulai dari pukul 20.00 - 22.00 setiap malam kecuali malam liburan dibawah bimbingan dan pengawasan santri senior dan ustadz/ah pengasuh, Bagi santri yang tidak serius atau tidak hadir mengikuti kegiatan muzakarah kelompok dikenakan sanksi, sesuai dengan ditetapkan pesantren. " (Wawancara dengan Drs. H. Syahrizulnur Pimpinan Pesantren pada tanggal 17 September 2016) 
Dari informasi tersebut, dapat dipahami bahwa selain belajar di sekolah, santri juga diwajibkan pula melakukan pengajian kitab kuning secara berkelompok (muzakarah) setiap malam sesuai dengan waktu yang sudah ditentukn pesantren, Pengajian dalam belajar kelompok, para santri yang terdiri dari beberapa orang berkumpul untuk membahas satu tema tertentu yang ada dalam sebuah kitab, dengan cara menunjuk salah seorang dari anggota kelompok untuk membaca kata perkata, kalimat demi kalimat, sedang yang lainnya mendengar. Kemudian masing-masing dari anggota kelompok mengoreksi dan menyimak bacaan tersebut. Setelah itu, masing-masing dari anggota kelompok mengulangi bacaan tadi secara bergantian sehingga lancar dan paham apa yang dibaca dari teks kitab tersebut.

Selain pengajian kelompok (muzakarah), diperoleh pula imformasi dari ustadz lain, yang menyebutkan bahwa:

"Santri diwajibkan pula melakukan pengajian secara mandiri, yaitu mengulangi kembali atau menghafal pelajaran yang sudah diajarkan ustadz/ah di pesantren, waktu yang digunakan adalah setelah sholat Subuh dan Maghrib. Selain waktu yang sudah dijadwalkan tersebut, ada lagi waktu khusus, yaitu bagi santri yang belajar pagi hari diwajibkan mengulangi kembali atau menghafal pelajaran yang sudah dipelajarinya pada sore hari, mulai dari pukul 1.30 - 15.00 (menjelang Ashar).

Sedangkan bagi santri yang belajar sore, wakktu mengulangi atau menghafalnya adalah pada pagi hari, mulai dari pukul 7.30 - 90.30 wib, kecuali hari libur ". (Wawancara dengan Taufik Guru Pesantren pada tanggal 17 September 2016)

Dari informasi tersebut, dapat dipahami bahwa pesantren mewajibkan para santrinya untuk mengulangi kembali atau menghafal pelajaran yang sudah dipelajarinya di pesantren, waktunya setelah sholat Subuh dan Maghrib. Selain waktu yang sudah dijadwalkan tersebut, pesantren menentukan lagi waktu khusus untuk mengulangi kembali atau menghafal pelajaran yang sudah dipelajari santri. Bagi santri yang belajar pagi hari diwajibkan mengulangi kembali atau menghafal pelajaran yang sudah dipelajarinya pada sore hari, mulai dari pukul 1.30 - 15.00 (menjelang Ashar). Sedangkan bagi santri yang belajar sore, wakktu mengulangi atau menghafalnya adalah pada pagi hari, mulai dari pukul 7.00 09.30 wib. Cara seperti ini berlangsung pada setiap hari kecuali hari liburan.

Disamping melakukan wawancara peneliti juga melakukan pengamatan yang dilakukan pada tanggal 17 September 2016 pada saat pembelajaran kitab Tauhid yang diampu oleh ustadz Muhammad Yasir, yang mana hasil pengamatan menunjukkan bahwa ustadz 
memberikan sanksi bagi siswa yang terlambat datang berupa tidak boleh duduk pada saat mengikuti kegiatan pembelajaran. Begitu juga bagi santri yang tidak mampu membacakan kembali pelajaran yang sudah berlalu bila disuruh ke depan kelas membacakannya. Dan ini juga merupakan faktor yang dapat mendukung proses pembelajaran, karena disamping dapat melatih kedisiplinan juga memotivasi santri untuk tekun mengikuti pembelajaran kitab kuning khususnya.

Berdasarkan imformasi dan pengamatan, menurut hemat peneliti bahwa proses belajarmengajar kitab kuning di pesantren mengunakan pendekatan tradisional, praktis, simple dan aplikatif. Adapun metode yang diterapkan di pesantren adalah metode klasikal, artinya kadang kala ustadz/ah yang membacakan sebuah teks kitab kuning, kemudian memberikan makna kata perkata, dan selanjutnya memberikan penjelasan. Dalam hal ini. santri hanya mendengarkan penyampaian ustadz. Dan terkadang santri diminta membacakan, kemudian menerjemahkannya. Apabila ada kesalahan, maka santri lain akan menegur dan ustadz/ah membimbing dan memberikan penjelasan panjang lebarnya.

Metode pembelajaran kitab kuning seperti yang diterapkan di pesantren Daarun Nahdhah menggunakan metode campuran (mixed methods). Artinya terkadang sang ustadz/ah yang membacakannya secara aktif, santri hanya mendengar atau meyimak bacaan dan penjelasan sang ustadz/ah. Dan terkadang santri yang aktif, artinya santri membaca kata per kata, sang ustaz/ah membimbing dan memberikan penjelasan. Dengan demikian, metode pembelajaran kitab kuning lebih menekankan pada transmisi ilmu pengetahuan dari ustaz/ah kepada santri, meskipun santri diberikan kesempatan untuk berpartisipasi secara aktif, namun santri hanya membaca dan menerjemahkan kata perkata, tanpa memberikan penjelasan dan analisis terhadap materi yang menjadi pembahasan dalam kitab tersebut.

Apabila diperhatikan metode pembelajaran kitab kuning yang digunakan Pesantren Daarun Nahdhah, kelihatannya tidak jauh berbeda dengan metode pembelajaran kitab kuning di pesantren lain di Nusantara (Jawamisalnya). Mereka menggunakan metode bandongan dan sorogan. Metode bandongan yang diterapkan Pesantren Daarun Nahdhah sesuai dengan pemikiran Zamakhsyari Dhofier dan Endang Turmudi. Menurut Zamakhsyari Dhofier, metode bandongan adalah penyampaian kitab dimana seorang guru, kiai, atau ustadz membacakan dan menjelaskan isi kitab, sementara santri, murid, atau siswa mendengarkan, memberikan makna, dan menerima." Sementara Endang Turmudi pula menyebutkan bahwa dalam metode ini kyai hanya membaca salah satu bagian dari sebuah bab dalam sebuah kitab, menerjemahkannya ke dalam bahasa Indonesia dan memberikan 
penjelasan-penjelasan yang

diperlukan.(Endang Turmudi:2004)

Sedangkan pembelajaran kitab

kuning dengan menggunakan

metode sorogan yang diterapkan

Pesantren Daarun Nahdhah sesuai

dengan pemahaman Husein

Muhammad, yaitu santri membaca sedangkan usutadz/ah

mendengarkan sambil memberi catatan, komentar, atau bimbingan bila diperlukan. (Sa'id Aqiel Siradj dkk:2004)

Dari pemikiran di atas, dapat dipahami bahwa metode yang disebut terakhir ini memiliki kelebihan dibandingkan metode bandongan di sebut di atas, karena metode sorogan memiliki efektivitas dan signifikansi yang tinggi dalam mencapai hasil belajar. Selain itu, metode ini juga memberikan kesempatan pada ustadz/ah mengawasi, menilai, dan membimbing secara maksimal kemampuan santri dalam penguasaan materi kitab kuning.

\section{E. Faktor Pendukung dan Penghambat}

Seperti dimaklumi bahwa kegiatan pembelajaran kitab kuning di pondok pesantren bertujuan untuk membentuk kepribadian santri yang islami, ta'at melaksanakan ibadah sesuai dengan syari'at yang telah ditentukan. Akan tetapi, setiap kegiatan apapun bentuknya pasti ada terdapat faktor pendukung maupun penghambat, baik yang datangnya dari dalam maupun dari luar. Begitu pula dalam kegiatan pembelajaran kitab kuning, ada banyak faktor yang mempengaruhi, yaitu berupa faktor pendukung dan ada pula berupa faktor penghambat terutama bagi para santri. Maksud faktor pendukung di sini adalah halhal yang lebih memudahkan santri dalam pembelajaran kitab kuning, sehinnga membuat santri mampu menguasainya. Sedangkan faktor penghambat, maksudnya adalah santri merasa kesulitan atau merasakan ada hambatan dalam mengikuti proses pembelajaran kitab kuning tersebut.

Berdasarkan observasi dan wawancara peneliti, dari beberapa penuturan para pengajar/ustadz di pondok pesantren tersebut, ada beberapa faktor pendukung utama pembelajaran kitab kuning di Pondok Pesantren Daarun Nahdhah dapat dirinci sebagai berikut:

1. Dari segi materi adalah ilmu alat, yaitu berupa nahwu dan sharaf. Adanya penguasaan santri dengan ilmu alat, sehingga santri mampu membaca dan memahami kitab-kitab kuning lainnya.

2. Dari segi fisik yaitu antusiasme santri yang cukup tinggi dalam mengikuti pembelajaran kitab kuning,. Dengan semangat santri tersebut, tentu saja akan menjadikan spirit tersendiri bagi ustadz/ah pengampu dalam pembelajaran kitab kuning.

3. Diikat dengan peraturan yang kuat, sehingga dengan ditunjang dengan peraturan yang cukup ketat, santri bisa disiplin dalam mengalokasikan waktu, 
terutama dalam pembelajaran kitab kuning.

4. Ditambah lagi siswa banyak diberi kegiatan-kegiatan, sehingga tidak ada waktu nganggur. Absensi juga berjalan terus baik ketika di asrama ataupun di sekolah.

5. Adanya sanksi, terutama bagi santri yang mengabaikan waktu dan yang tidak mampu membaca kitab kuning.

6. Faktor lingkungan tempat tinggal (mondok/di asrama) juga menentukan keberhasilan santri dalam proses poembelajaran kitab kuning, karena santri mudah dibina dan dipantau secara langsung dan dikontrol setiap saat.

7. Tenaga pengajar Kitab Kuning juga mumpuni, karena merupakan lulusan pondok pesantren dan perguruan tinggi baik negeri maupun swasta.

Sedangkan penghambat pembelajaran kitab kuning pula, ada beberapa faktor, sebagaimana dituturkan oleh ustadz lain:

1. Latar belakang yang pendidikan yang berbeda, sebagian santri adalah tamatan Sekolah Dasar (negeri maupun swasta) yang minim atau bahkan tidak pernah mempelajari dasar-dasar Bahasa Arab.
2. Tidak semua santri bersemangat untuk mempelajari Kitab Kuning.

\section{F. Solusi Untuk Hambatan}

Menurut wawancara mengenai solusi yang ditempuh dalam menangani hambatan atau problem yang dihadapi dalam pembelajaran kitab kunng di Pondok Pesantren Daarun Nahdhah Bangkinang didapat penjelasan sebagai berikut :

1. Membenahi sistem pembelajaran dengan memperketat kedisiplinan santri dan guru.

2. Mendorong para guru untuk menerapkan pembelajaran yang aktif dan komunikatif.

3. Memberikan motivasi kepada santri melalui metode story telling yang dikemas menarik, terutama kisahkisah teladan tokoh-tokoh muslim terdahulu.

\section{G. Kesimpulan}

Berdasarkan pemaparan dan analisa data yang telah penulis uraikan di atas, maka dapat diambil kesimpulan Pondok Pesantren Daarun Nahdhah Bangkinang merupakan lembaga pendidikan agama yang masih tetap kukuh menggunakan kitab-kitab kuning dalam sistem pembelajarannya.

Adapun pembelajaran kitab kuning di pesantren dilakukan dalam dua bentuk; yaitu secara mandiri dan secara berkelompok. Sedangkan metode pembelajaran kitab kuning yang diterapkan pesantren dalam mentransfer keilmuan adalah 
Ali Akbar, Hidayatullah Ismail; Metode Pembelajaran Kitab Kuning di Pondok Pesantren Daarun Nahdhah Thawalib Bangkinang

menggunakan metode campuran ( $m i x e d$ methods), yaitu adakalanya bandongan dan adakalanya sorogan.

\section{DAFTAR PUSTAKA}

Bungin, Burhan. Metodologi Penelitian Kualitatf. Jakarta: Raja Grafindo Persada. 2007.

http://ponpesdaarunnahdhah.sch.id/ visi-dan-misi. Diakses pada pukul 22.30 WIB tanggal 12 September 2016.

Masdar F. Mas'udi. Pergulatan Pesantren. Jakarta: P3M. Tt.

Muhaimin. Pemikiran Pendidikan Islam. Bandung: Trigenda Karya. 1993.

Muqoyyidin, Andik Wahyun. Kitab Kuning dan Tradisi Riset Pesantren di Nusantara. Jurnal Ibda': Jurnal Kebudayaan Islam, Vol 2, No. 2, Juli-Desember 2014.

Qomar, Mujamil. Strategi Baru Pengelolaan Lembaga Pendidikan Islam; Manajemen Pendidikan Islam. Jakarta : Erlangga. 2007.

Saridjo, Marwan. dkk, Sejarah Pondok Persantren di Indonesia. Jakarta : Dharma Bhakti. 1982.

Siradj, Sa'id Aqiel. Dkk. Pesantren Masa Depan. Cirebon: Pustaka Hidayah. 2004.

Syafe'i, Imam. Model Kurikulum Pesantren Salafiyah dalam Perspektif Multikultural. Jurnal Al Tadzkiyyah: Jurnal
Pendidikan Islam, Volume 8, Edisi II. 2017.

Thariqussu'us, Muhammad. Modelmodel Pengembangan Kajian Kitab Kuning di Pondok Pesantren. Jurnal At Tajdid: Jurnal IImu Tarbiyah. Volume 1, No.2, Juli 2012.

Turmudi, Endang. Perselingkuhan Kiai dan Kekuasaan. Yogyakarta: LkiS. 2004. 